International Journal of Physical Sciences and Engineering
Available online at www.sciencescholar.us
Vol. 5 No. 3, December 2021, pages: $34-43$
e-ISSN : 2550-6943, p-ISSN : 2550-6951
https://doi.org/10.53730/ijpse.v5n3.1723

\title{
Analysis of Gravity Anomaly and Seismicity in Bali Region
}

\begin{abstract}
Alfha Abrianto L. Tobinga, I Ketut Sukarasa ${ }^{\text {b }}$, Mahmud Yusuf c
Manuscript submitted: 09 August 2021, Manuscript revised: 18 September 2021, Accepted for publication: 27 October 2021

\section{Corresponding Author ${ }^{\text {a }}$}

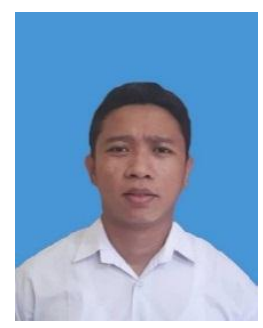

\section{Keywords}

gravity anomaly;

seismicity;

SVD;

Abstract

This study aims to determine the value of the gravity anomaly in the Bali region, identify the fault structure in the Bali region using gravity interpretation and analyze the relationship between gravity anomaly and seismicity in the Bali region. The data used is secondary data, namely satellite gravity anomaly data obtained from the topex website and earthquake data obtained from the Indonesian Agency for Meteorological, Climatological, and Geophysics (BMKG) catalog. Data processing in this study was done using gravity and Second Vertical Derivative (SVD) methods. We used Surfer15 software, Oasis Montaj, and the Generic Mapping Tool (GMT). The results of the complete Bouguer anomaly map show the anomalous value of the study area between 10-220 mGal, regional anomaly 40-190 mGal, and the residual anomaly between (120)-60 mGal. Judging from the SVD contour map that has included earthquake data in the Bali region for the 2008-2020 period, the type of fault in the Seririt Fault, Tejakula Fault, and Fault around Mount Agung is a thrust fault. Judging from the value of the coefficient of determination, it shows that $99 \%$ of the seismicity value is influenced by gravity anomaly. The higher the value of the gravity anomaly, the higher the seismicity value.
\end{abstract}

International Journal of Physical Sciences and Engineering (C) 2021. This is an open access article under the CC BY-NC-ND license (https://creativecommons.org/licenses/by-nc-nd/4.0/).

\section{Contents}

Abstract

1 Introduction...

Materials and Methods

3.1 Anomaly of Gravity in the Bali Region

3.2 Interpretation of the fault structure after separating the regional anomaly and the residual anomaly

3.3 Analysis of seismicity.

3.4 Gravity anomaly and seismicity analysis

\footnotetext{
a Udayana University, Denpasar, Indonesia

b Udayana University, Denpasar, Indonesia

c Region III Major Meteorology, Climatology, and Geophysics Center, Badung, Indonesia
} 
4 Conclusion

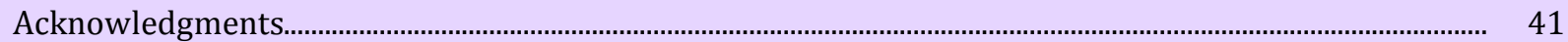

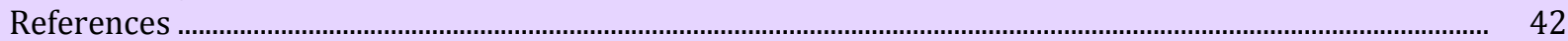

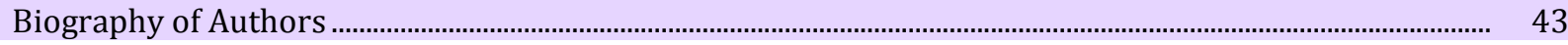

\section{Introduction}

The island of Bali is part of the Lesser Sunda archipelago which was formed as a result of the subduction process of the Indo-Australian plate under the Eurasian plate. The subduction process gives rise to tectonic activity (Daryono, 2011). Based on these tectonic conditions, seismic activity in Bali is strongly influenced by two earthquake generators, namely plate subduction activity, and local fault activity. The distribution of the epicenter was spread to the south and north of the island of Bali, mostly concentrated in the southern arc of the islands of Java, Bali, and Nusa Tenggara. Seismicity activity located around the ocean trench is an earthquake caused by plate subduction. Shallow earthquake activity centered on the mainland of Bali is mostly caused by active fault activities such as the Negara Fault, Seririt Fault, and Tejakula Fault which generally has a northwest-southeast or west-east direction (McCaffrey, 1987).

The high seismic activity on the island of Bali causes the island of Bali to be vulnerable to seismic activity, making it prone to earthquakes. Therefore, it is necessary to research to see earthquake-prone areas by comparing the results of the value of the gravity anomaly with the seismicity map of the Bali region which will later be able to interpret the fault structure in the Bali region using gravity data (Casas et al., 1997; Niu et al., 2001). Based on the explanation above, the writer analyzes the gravity and seismicity anomaly in the Bali region. In this study, we used gravity and SVD methods (Scharf, 1991). The final result of this study is expected to provide information about the subsurface structure of the Bali region for the benefit of disaster mitigation studies, exploration, and others.

\section{Theoretical foundation Geology of Bali}

The regional geological structure of Bali begins with activity in the oceans during the lower Miocene which produced pillow lava rocks and breccias interlaced with limestone. The stratigraphy in Figure 1 shows that the geology of Bali is still relatively young. The oldest rocks are probably from the middle Miocene.

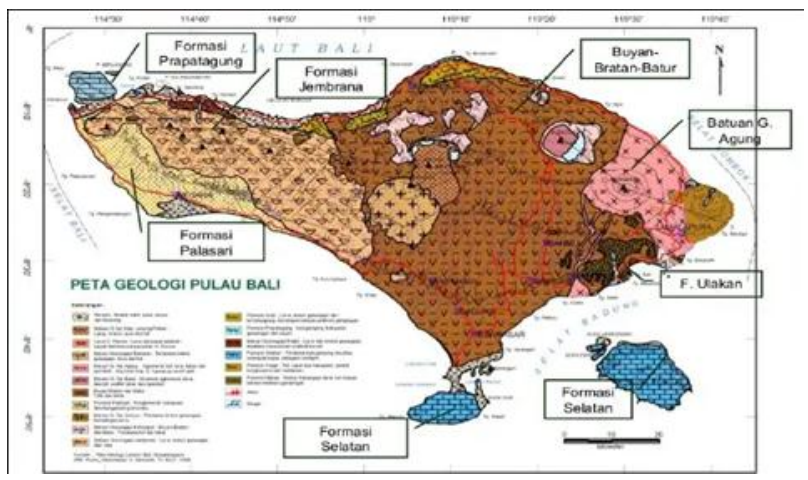

Figure 1. Geological map of Bali Island (Hadiwidjojo et al., 1998)

\section{Gravity theory}

The theory of gravity is based on Newton's law of gravity. Newton's law of gravity states that the magnitude of the attractive force between two objects is proportional to the masses of the two objects and inversely

Tobing, A. A. L., Sukarasa, I. K., \& Yusuf, M. (2021). Analysis of gravity anomaly and seismicity in Bali region. International Journal of Physical Sciences and Engineering, 5(3), 34-43. 
proportional to the square of the distance between the centers of mass of the two objects (Kearey et al., 2002). Mathematically, the formula for gravity is like equation (1), below.

$$
\vec{a}=\vec{g}=-\frac{G M}{R^{2}} \vec{r}
$$

\section{Data reduction for gravity}

In general, the magnitude of the gravitational field is influenced by five factors, namely latitude, altitude, topography around the field, tides, and density variations below the surface. Measurement of gravity required data reduction to separate gravity anomaly. The separation is carried out by considering the observed gravity anomaly and the theoretical gravity anomaly (Biswas, 2015; Molina-Garza \& Urrutia-Fucugauchi, 1993). That is, the gravity anomaly is determined by calculating the difference between the observed gravity anomaly and the theoretical gravity anomaly. In measuring gravity, several corrections are needed, namely earth tide correction, buoyancy correction, latitude correction, free air correction, Bouguer correction, and terrain correction (Telford et al., 1990).

\section{Parasnis method}

The Parasnis method is an analytical method to determine the average rock density estimate with the assumption that the topography of the research area is relatively flat (Martha, 2011). This method only requires elevation data (h), free air anomaly data, field correction values, and bouger correction values calculated without density. Mathematically, the calculation using the Parasnis method is derived from the equation:

$$
\begin{aligned}
& (\text { gobs }-g \phi-0,3085 h)-C B A=(2 \pi \gamma h-c) \rho \\
& F A A-C B A=B C-T C \\
& \frac{B C}{\rho}-\frac{T C}{\rho}=2 \pi \gamma h-c
\end{aligned}
$$

where $\mathrm{c}$ is the value of the field correction before it is multiplied by the density. If simplified, the above equation can be written as in equation (5).

$$
y=\rho x+C B A
$$

\section{Spectrum analysis}

Spectrum analysis was carried out to see the anomalous response originating from the regional, residual, and noise zones so that the depth of the gravity anomaly could be estimated. The spectrum analysis method uses the Fourier transform to convert a function in distance or time into a function in wavenumber or frequency (Blakely, 1995). Spectrum analysis is done by making a trajectory that is considered representative of the research area. The results of the Fourier transform are then graphed between ln A (amplitude) on the y-axis vs $\mathrm{k}$ (wavenumber) on the $\mathrm{x}$-axis.

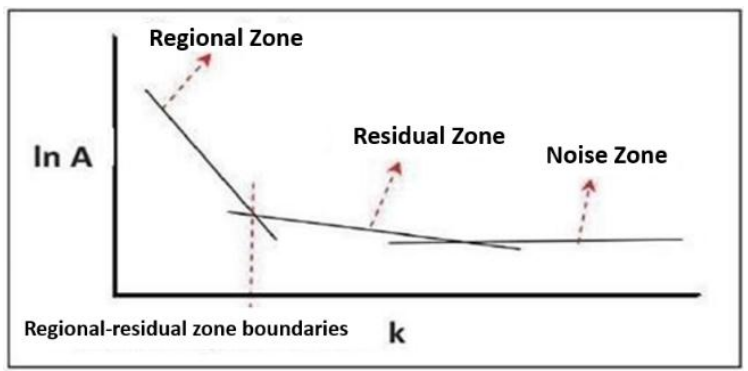

Figure 2. The curve of ln A against k (Blakely, 1995) 
Estimation of the depth of each anomaly can be done by performing linear regression in each zone. Regional depth will be obtained by performing linear regression on regional zones, as well as residual and noise depths.

\section{Separation of regional anomaly and residual anomaly}

In the separation of a regional and residual anomaly in this study, the CBA moving average data method is used. This method will produce output in the form of regional anomaly. A residual anomaly is obtained from the difference between the Bouguer anomaly and the regional anomaly. Anomaly separation using moving alignment acts as a low pass filter (filtering out the high-frequency wave anomaly). The wider the window used, the value of the residual anomaly will approach the value of the Bouguer anomaly. The result of this average is the regional anomaly. While the residual anomaly is obtained by subtracting the data from the gravity measurement with the regional anomaly (Purnomo et al., 2013).

\section{The Second Vertical Derivative Method (SVD)}

The Second Vertical Derivative (SVD) method is a method used to separate the shallow effect (residual anomaly) from the Bouguer anomaly (Reynold, 2011). SVD is a high pass filter, so it can describe residual anomaly and can be used to identify the type of fault (up or normal) to the Bouguer anomaly (Sarkowi, 2012; Telford et al., 1990). The criteria for determining the type of fault are as follows:

$$
\begin{aligned}
& \text { Fault down: } \\
& \left|\frac{\partial^{2} \Delta g}{\partial z^{2}}\right|_{\text {min }}<\left|\frac{\partial^{2} \Delta g}{\partial z^{2}}\right|_{\text {max }} \\
& \text { Fault up: } \\
& \left|\frac{\partial^{2} \Delta g}{\partial z^{2}}\right|_{\text {min }}>\left|\frac{\partial^{2} \Delta g}{\partial z^{2}}\right|_{\text {max }} \\
& \text { Shear fault: } \\
& \left|\frac{\partial^{2} \Delta g}{\partial z^{2}}\right|_{\text {min }}=\left|\frac{\partial^{2} \Delta g}{\partial z^{2}}\right|_{\text {max }}
\end{aligned}
$$

Fault

A fault is a condition where there is movement or shift of rock due to geological forces. The easiest way to see if there is a fault or not in an area is to look at the offset in that area because that is the most widely used feature to find a fault on this earth. In a fault, the plane that is fractured is called a fault. In general, there are 3 main groups of faults, namely ascending faults, normal faults, and horizontal faults.

\section{Materials and Methods}

This research was conducted at the Center for Meteorology, Climatology and Geophysics Region III Denpasar and Udayana University Bukit Jimbaran Campus. The research was carried out from April to August 2021.

\section{Materials and tools}

This research uses several tools. The tools used include software, namely Microsoft Word 2016, Microsoft Exel 2016, Generic Mapping Tool (gmt-6.1-win64), Surfer15, and Oasis Montaj 8.4. While the material in this study is in the form of earthquake data sourced from the BMKG catalog (http://repogempa.bmkg.go.id/) in 20082020 with a magnitude of 1-10 SR at a depth of $0-700 \mathrm{~km}$, and gravity data obtained from the Topex website (http://topex.ucsd.edu/cgi-bin/get_data.cgi).

Tobing, A. A. L., Sukarasa, I. K., \& Yusuf, M. (2021). Analysis of gravity anomaly and seismicity in Bali region. International Journal of Physical Sciences and Engineering, 5(3), 34-43. https://doi.org/10.53730/ijpse.v5n3.1723 


\section{Information processing}

Gravity informationThe data used is gravity anomaly data that has been corrected to free air obtained from the Topex website (Farfán et al., 2021). The data is carried out with Bouguer correction and field correction to obtain complete Bouguer anomaly data. The complete Bouguer anomaly data is gridd on the surfer15 software, which will then be analyzed by spectrum to determine the estimated depth of the study area using the Oasis Montaj software. After performing the spectrum analysis, the regional and residual anomaly will be separated using the moving average filter in Surfer15 software. Then after separating regional anomaly and residual anomaly, interpreting the structure to determine the type of fault in the study area using the Second Vertical Derivative (SVD) method where the results of the residuals are brought to the Oasis Montaj software (Chang et al., 2005; Vozalis \& Margaritis, 2007). Furthermore, slicing was carried out on the SVD contour by plotting earthquake data from 2008-2020 on the Surfer15 software. The result is an earthquake map with SVD contours containing the distribution of the earthquake where later it will be known the area to be sliced to determine the type of fault from the research area. Earthquake information earthquake data for the period 2008-2020 will be plotted on the GMT software for seismicity mapping, where the results of the plot will produce a seismicity map showing areas with high seismicity and types of earthquakes based on their magnitude and depth (Chiarabba et al., 2005).

\section{Results and Discussions}

\subsection{Anomaly of Gravity in the Bali Region}

In mapping, the gravity anomaly in the Bali region, griding, and contouring of complete Bouguer anomaly data were carried out using Surfer15 software, so that the contour map results were shown in Figure 3.

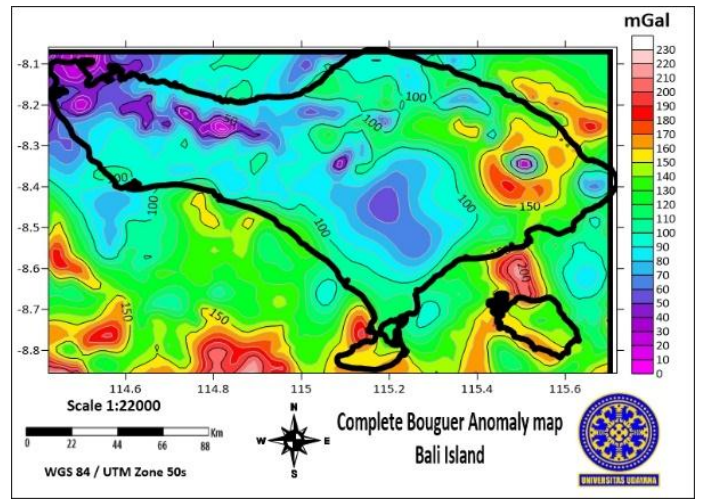

Figure 3. Complete bouguer anomaly map of the island of Bali.

From the complete Bouguer anomaly map of the island of Bali, the anomaly value range is between 10-220 $\mathrm{mGal}$. The high anomaly has a green to red color with anomalous value ranges between 100-220 mGal and it can be seen that the distribution of high anomaly values is spread in the northeast, which is more inclined to the southwest to the southeast, while the low anomaly has a purple to a blue color with anomalous values between 10-60 mGal spread in the northwest to the east. Then the regional and residual anomalies are separated, where the results of the grid on Surfer15 in the form of contour maps of the regional and residual anomaly are obtained (Doniyor \& Khabibulla, 2021).

\subsection{Interpretation of the fault structure after separating the regional anomaly and the residual anomaly}

Then the structure interpretation is carried out to determine the type of fault in the study area using the SVD method. Then slicing is done on the SVD contour by plotting earthquake data from 2008-2020 with Surfer15 
software where the earthquake plot image with SVD contours is shown in Figure 4. For example, the SVD value of $1.8 \mathrm{E}-05$ can be interpreted as $1.810-5 \mathrm{~m}$.

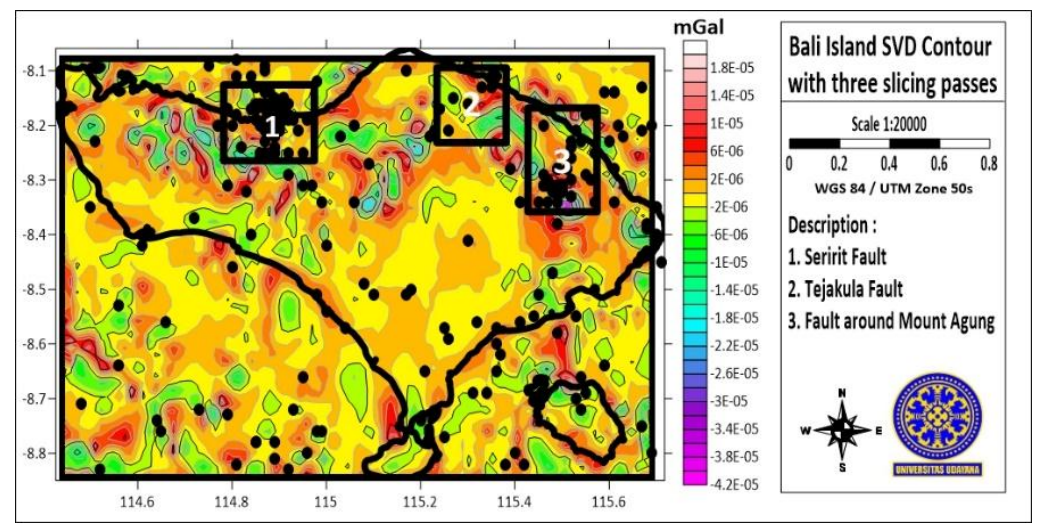

Figure 4. SVD contours with plots of 2008-2020 earthquake data, and slicing in the Seririt Fault, Tejakula Fault, and the area around Mount Agung

The results of determining the type of fault in the slicing area using SVD in detail are presented in graphical form in Figure 5 below.
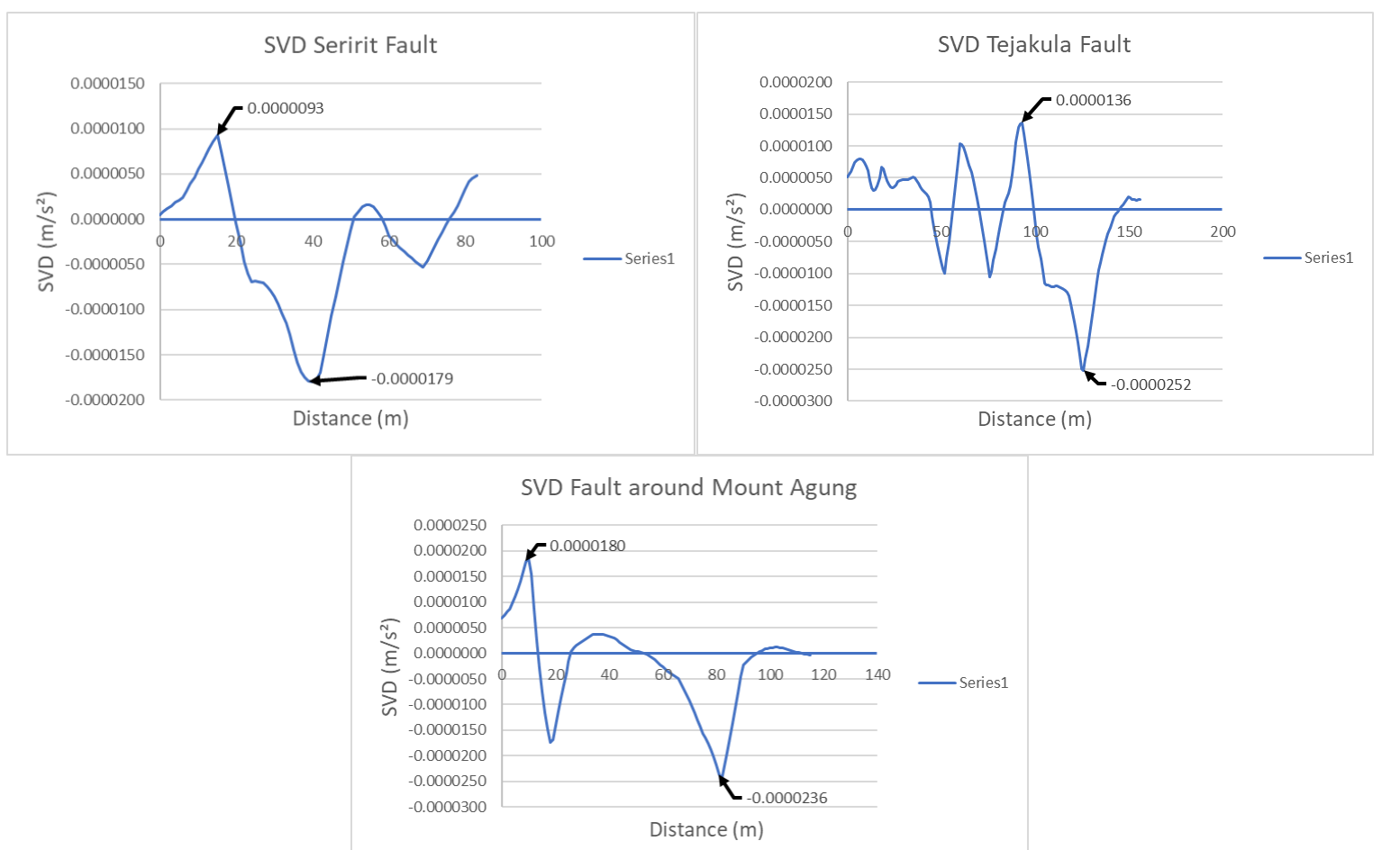

Figure 5. SVD graph of the Seririt Fault, Tejakula Fault, and the area around Mount Agung

From the graph shown in Figure 5, it shows that the type of fault produced in this anomaly is an ascending fault because the absolute value of the minimum SVD is greater than the absolute value of the maximum SVD. It can be concluded that the Seririt Fault, Tejakula Fault, and the faults around Mount Agung are affected by the rising fault.

Tobing, A. A. L., Sukarasa, I. K., \& Yusuf, M. (2021). Analysis of gravity anomaly and seismicity in Bali region. International Journal of Physical Sciences and Engineering, 5(3), 34-43. https://doi.org/10.53730/ijpse.v5n3.1723 


\subsection{Analysis of seismicity}

In the seismic analysis using the GMT 6 software, the results of the running program are in the form of a map with earthquake points generated from the 2008-2020 earthquake data input, which is shown in Figure 6 in the form of information in the form of graphs and seismicity maps of the island of Bali (Kerrick \& Connolly, 2001).

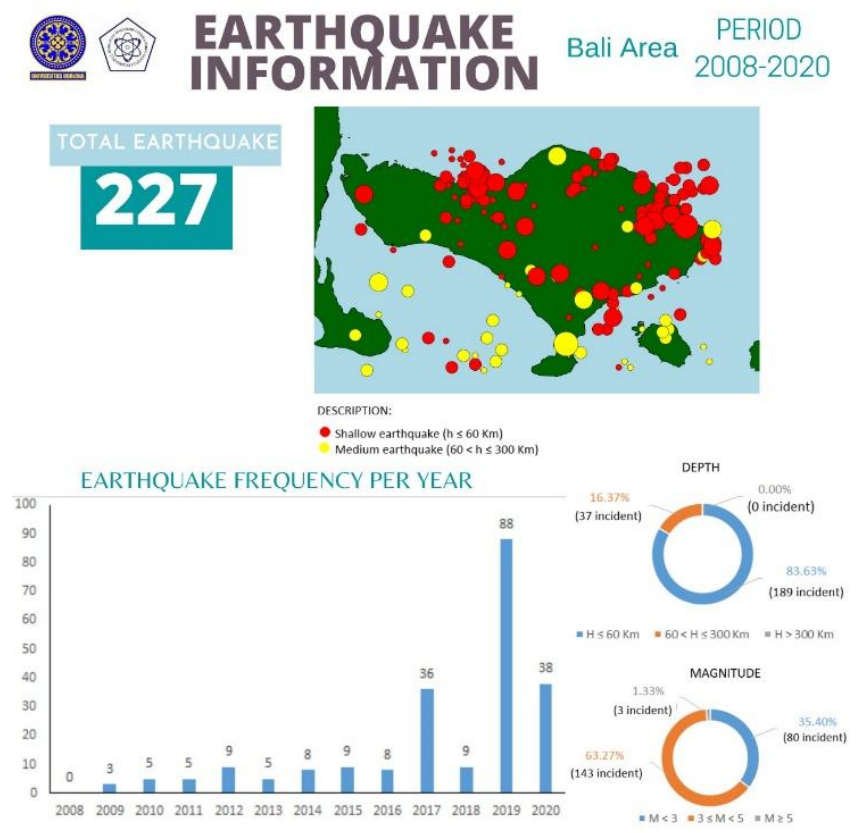

Figure 6. Map of Bali Island seismicity information in 2008-2020

Then the seismic information map of Bali Island for 2008-2020 is shown in Figure 6. Based on the map, it shows that seismicity on the island of Bali is mostly influenced by shallow earthquakes with a depth of fewer than $60 \mathrm{~km}$. This is reinforced by the depth graph where seismicity occurs at a depth of fewer than $60 \mathrm{~km}$, with as many as 189 events with a percentage of $83.63 \%$. Meanwhile, the magnitude graph shows the most occurrences at magnitudes between 3 and 5, wherein in the magnitude range there are 143 events with a percentage of $63.27 \%$. Based on the histogram graph, the frequency of earthquakes occurred more in 2019 with 88 events.

\subsection{Gravity anomaly and seismicity analysis}

The results of the analysis of gravity and seismicity anomaly in the Bali region are shown in Figure 7.
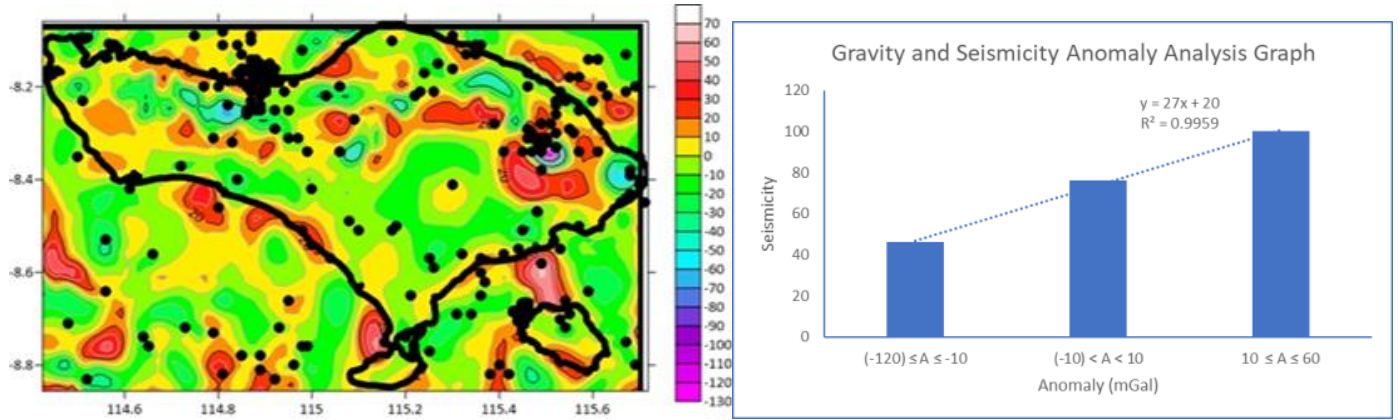

Figure 7. Residual map with earthquake plots for the period 2008-2020 (left) and graph of the relationship between gravity and seismicity anomaly in the Bali region (right) 
From the residual contour map of the Bali region by plotting earthquake data for the 2008-2020 period, 227 data points are shown in Figure 7 (left). The figure shows that earthquakes often occur at high Bouguer anomaly values with a value range of 10-60 mGal. A high residual anomaly value indicates the presence of rocks with a higher density.

The graph in Figure 7 (right) shows that the gravity anomaly with a range of 10-60 mGal has a seismicity distribution point with a percentage of $45 \%$, while the gravity anomaly of $-120-(-10)$ mGal has a seismicity distribution point with a percentage of $21 \%$. It can also be seen from the linear regression equation on the graph. The value of the coefficient of determination of 0.99 indicates that $99 \%$ of the seismicity value is influenced by the gravity anomaly (Ekström et al., 2005).

\section{Conclusion}

From the complete Bouguer anomaly contour map of the island of Bali, the value of the gravity anomaly is obtained with a range of anomaly values between 10-220 mGal. The high anomaly has anomalous value ranges between $110-220 \mathrm{mGal}$ and the low anomaly has anomalous value ranges between 10 and $80 \mathrm{mGal}$. Based on the Second Vertical Derivative (SVD) method, seen from the SVD contour map that has included earthquake data in the Bali region for the 2008-2020 period, the type of fault in the Seririt Fault, Tejakula Fault, and faults around Mount Agung is a fault thrust. Judging from the value of the coefficient of determination, it shows that $99 \%$ of the seismicity value is influenced by gravity anomaly. The higher the value of the gravity anomaly, the higher the seismicity value.

\section{Acknowledgments}

The author would like to thank BBMKG Region III Denpasar for providing facilities for this research. As well as lecturer staff in the fields of interest in Earth Physics, Physics Study Program, FMIPA, UNUD who have provided suggestions and input related to this research.

Tobing, A. A. L., Sukarasa, I. K., \& Yusuf, M. (2021). Analysis of gravity anomaly and seismicity in Bali region. International Journal of Physical Sciences and Engineering, 5(3), 34-43. 


\section{References}

Biswas, A. (2015). Interpretation of residual gravity anomaly caused by simple shaped bodies using very fast simulated annealing global optimization. Geoscience Frontiers, 6(6), 875-893. https://doi.org/10.1016/j.gsf.2015.03.001

Blakely, R. J. (1995). Potential Theory in Gravity \& Magnetic Aplications, 1st edition, New York,USA, Cambridge University States.

Casas, A., Kearey, P., Rivero, L., \& Adam, C. R. (1997). Gravity anomaly map of the Pyrenean region and a comparison of the deep geological structure of the western and eastern Pyrenees. Earth and Planetary Science Letters, 150(1-2), 65-78. https://doi.org/10.1016/S0012-821X(97)00087-3

Chang, C. C., Tsai, P., \& Lin, C. C. (2005). SVD-based digital image watermarking scheme. Pattern Recognition Letters, 26(10), 1577-1586. https://doi.org/10.1016/j.patrec.2005.01.004

Chiarabba, C., Jovane, L., \& DiStefano, R. (2005). A new view of Italian seismicity using 20 years of instrumental recordings. Tectonophysics, 395(3-4), 251-268. https://doi.org/10.1016/j.tecto.2004.09.013

Daryono, B. (2011). Identifikasi sesar naik belakang busur (back-arc thrust) daerah Bali berdasarkan seismisitas dan solusi bidang sesar. Artik. Kebumian Badan Meteorol. Klimatol. Geofis.

Doniyor, P., \& Khabibulla, P. (2021). Theoretical research of mechanics of yarns in assembly winding machines. International Research Journal of Engineering, IT \& Scientific Research, 7(5), 193-202. https://doi.org/10.21744/irjeis.v7n5.1928

Ekström, G., Dziewoński, A. M., Maternovskaya, N. N., \& Nettles, M. (2005). Global seismicity of 2003: Centroid-moment-tensor solutions for 1087 earthquakes. Physics of the Earth and Planetary Interiors, 148(2-4), 327-351. https://doi.org/10.1016/j.pepi.2004.09.006

Farfán, R. F. M., Zambrano, T. Y. M., Sosa, V. M. D., \& Zambrano, R. A. M. (2021). Design and construction of a thermoelectric system for high performance computers. International Journal of Physical Sciences and Engineering, 5(2), 25-33. https://doi.org/10.29332/ijpse.v5n2.1359

Hadiwidjojo, P. M. M., Samodera, H., \& Amin, T. C. (1998). Peta Geologi Lembar Bali, Nusa Tenggara (Geological Map of Bali, Nusa Tenggara). Scale 1: 100.000. Center for Geological Research and Development, Bandung.

Kearey, P., Brooks, M., \& Hill, I. (2002). An Introduction to Geophysical Exploration, Edisi ke-3.

Kerrick, D. M., \& Connolly, J. A. D. (2001). Metamorphic devolatilization of subducted oceanic metabasalts: implications for seismicity, arc magmatism and volatile recycling. Earth and Planetary Science Letters, 189(1-2), 19-29. https://doi.org/10.1016/S0012-821X(01)00347-8

Martha, A.A. (2011). Pemodelan 3D Data Gayaberat Lapangan Panas Bumi Ulubelu, Tanggamus, Lampung, Thesis, Institut Teknologi Bandung.

McCaffrey, R., \& Nabelek, J. (1987). Earthquakes, gravity, and the origin of the Bali Basin: An example of a nascent continental fold-and-thrust belt. Journal of Geophysical Research: Solid Earth, 92(B1), 441-460.

Molina-Garza, R., \& Urrutia-Fucugauchi, J. (1993). Deep crustal structure of central Mexico derived from interpretation of Bouguer gravity anomaly data.Journal of Geodynamics, 17(4), 181-201. https://doi.org/10.1016/0264-3707(93)90007-S

Niu, Y., Bideau, D., Hékinian, R., \& Batiza, R. (2001). Mantle compositional control on the extent of mantle melting, crust production, gravity anomaly, ridge morphology, and ridge segmentation: A case study at the Mid-Atlantic Ridge 33-35 N. Earth and Planetary Science Letters, 186(3-4), 383-399. https://doi.org/10.1016/S0012-821X(01)00255-2

Purnomo, J., Koesuma, S., \& Yunianto, M. (2013). Pemisahan anomali regional-residual pada metode gravitasi menggunakan metode moving average, polynomial dan inversion. Indonesian Journal of Applied Physics, 3(1), 10.

Reynolds, J. M. (2011). An introduction to applied and environmental geophysics. John Wiley \& Sons.

Sarkowi, M. (2012). Identifikasi struktur daerah panasbumi Ulubelu berdasarkan analisa data SVD anomali bouguer. Jurnal Sains MIPA Universitas Lampung, 8(2).

Scharf, L. L. (1991). The SVD and reduced rank signal processing. Signal processing, 25(2), 113-133. https://doi.org/10.1016/0165-1684(91)90058-Q

Telford, W. M., Telford, W. M., Geldart, L. P., \& Sheriff, R. E. (1990). Applied geophysics. Cambridge university press. 
Vozalis, M. G., \& Margaritis, K. G. (2007). Using SVD and demographic data for the enhancement of generalized filtering. Information

Sciences, 177(15),

3017-3037.

https://doi.org/10.1016/j.ins.2007.02.036

\section{Biography of Authors}

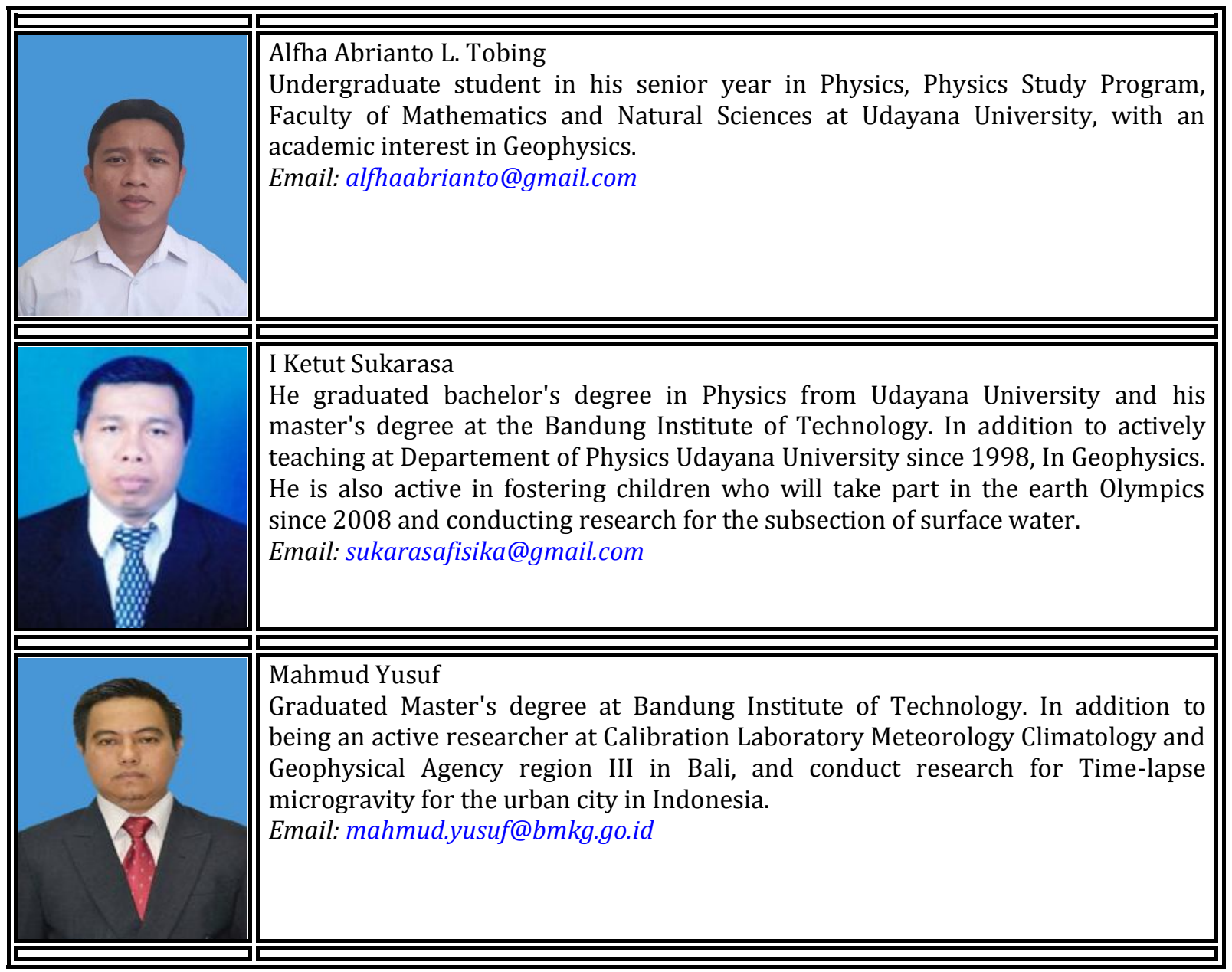

Tobing, A. A. L., Sukarasa, I. K., \& Yusuf, M. (2021). Analysis of gravity anomaly and seismicity in Bali region. International Journal of Physical Sciences and Engineering, 5(3), 34-43. https://doi.org/10.53730/ijpse.v5n3.1723 